\title{
Spatial Variability and Optimal Number of Rain Gauges for Sampling Throughfall under Single Oak Trees during the Leafless Period
}

\author{
Omid Fathizadeh ${ }^{1}(\mathbb{D})$, Seyed Mohammad Moein Sadeghi ${ }^{2}\left(\mathbb{D}\right.$, Iman Pazhouhan $^{3}\left(\mathbb{D}, \operatorname{Sajad}_{\text {Ghanbari }}{ }^{1}(\mathbb{D}\right.$, \\ Pedram Attarod ${ }^{4}$ (D) and Lei $\mathrm{Su}^{5, *(\mathbb{D})}$
}

1 Department of Forestry, Ahar Faculty of Agriculture and Natural Resources, University of Tabriz, Ahar 5451645857, Iran; omid.fathizadeh@yahoo.com (O.F.); ghanbarisajad@gmail.com (S.G.)

2 Technical Bureau of Forestry and Plantation, Natural Resources and Watershed Management Office of West Azerbaijan Province, Urmia 5719975898, Iran; moeinsadeghi@ut.ac.ir

3 Faculty of Natural Resource and Environment, Malayer University, Malayer 6571749647, Iran; imanpazhouhan@gmail.com

4 Department of Forestry and Forest Economics, Faculty of Natural Resources, University of Tehran, Karaj 3158777871, Iran; attarod@ut.ac.ir

5 International Joint Research Laboratory for Global Change Ecology, School of Life Sciences, Henan University, Kaifeng 475004, China

* Correspondence: sulei123456a@126.com or 10140141@vip.henu.edu.cn

Citation: Fathizadeh, O.; Sadeghi, S.M.M.; Pazhouhan, I.; Ghanbari, S.; Attarod, P.; Su, L. Spatial Variability and Optimal Number of Rain Gauges for Sampling Throughfall under Single Oak Trees during the Leafless Period. Forests 2021, 12, 585. https:// doi.org/10.3390/f12050585

Academic Editor: Filippo Giadrossich

Received: 4 March 2021

Accepted: 5 May 2021

Published: 7 May 2021

Publisher's Note: MDPI stays neutral with regard to jurisdictional claims in published maps and institutional affiliations.

Copyright: (c) 2021 by the authors. Licensee MDPI, Basel, Switzerland. This article is an open access article distributed under the terms and conditions of the Creative Commons Attribution (CC BY) license (https:// creativecommons.org/licenses/by/ $4.0 /)$.

\begin{abstract}
This study examined the spatial variability of throughfall $\left(T_{f}\right)$ and its implications for sampling throughfall during the leafless period of oak trees. To do this, we measured $T_{f}$ under five single Brant's oak trees (Quercus brantii var. Persica), in the Zagros region of Iran, spanning a six-month-long study period. Overall, the $T_{f}$ amounted to $85.7 \%$ of gross rainfall. The spatial coefficient of variation $(\mathrm{CV})$ for rainstorm total $T_{f}$ volumes was $25 \%$, on average, and it decreased as the magnitude of rainfall increased. During the leafless period, $T_{f}$ was spatially autocorrelated over distances of 1 to $3.5 \mathrm{~m}$, indicating the benefits of sampling with relatively elongated troughs. Our findings highlight the great variability of $T_{f}$ under the canopies of Brant's oaks during their leafless period. We may also conclude that the $29 T_{f}$ collectors used in the present study were sufficient to robustly estimate tree-scale $T_{f}$ values within a $10 \%$ error of the mean at the $95 \%$ confidence level. Given that a $\pm 10 \%$ uncertainty in $T_{f}$ is associated with a $\pm 100 \%$ uncertainty in interception loss, this underscores the challenges in its measurement at the individual tree level in the leafless season. These results are valuable for determining the number and placement of $T_{f}$ collectors, and their expected level of confidence, when measuring tree-level $T_{f}$ of scattered oak trees and those in forest stands.
\end{abstract}

Keywords: geostatistic; leafless period; Quercus brantii var. Persica; sampling design; throughfall; variogram; Zagros forests

\section{Introduction}

Tree canopies significantly affect the terrestrial hydrological cycle by modifying the distribution of water received during rainfall events. The partitioning of gross rainfall $\left(P_{g}\right)$ into throughfall $\left(T_{f}\right)$, stemflow $\left(S_{f}\right)$, and rainfall interception $(I)$ by the forest canopy layer has a major role in structuring the water budget of forest ecosystems [1-4]. The $T_{f}$ can be further divided into free throughfall, the water reaching the forest floor without coming into contact with vegetation, and release throughfall, which splashes or drips downward from the canopy [5]. Not only does the presence of trees affect the amount of water reaching the forest floor, but it also determines the spatial distribution of $T_{f}$ [6,7].

The spatial variability of $T_{f}$ potentially exercises considerable control of forest hydrology and biogeochemistry dynamics because it can lead to pronounced heterogeneity in edaphic conditions [8,9]. To optimize forest management in terms of the availability 
of water and nutrition in the soil, a better understanding of the spatial distribution of $T_{f}$ within forests and its controls is imperative [10].

To date, the spatial redistribution of water under single trees (i.e., 'open-grown trees', those developing sufficiently apart from other to form full canopies and maximum branching) remains understudied. As noted above, $T_{f}$ is spatially variable due to heterogeneity imposed by variation in canopy structure (e.g., foliage and branch cover) and the proximity of tree boles onto the free throughfall and/or canopy drip patterns [10]. Nonetheless, literature reviews in hydrology have documented positive [11,12], negative [13,14], and inconsistent relationships $[15,16]$ between where $T_{f}$ is sampled and nearness to the tree bole; therefore, their spatial dynamics can vary substantially across sites and tree types and we cannot generalize these patterns. Many such studies were done in architecturally simple conditions, for example in even-aged stands, yet $T_{f}$ can be highly variable at small spatial scales, namely beneath single trees [16,17]. Although researchers have reported on $T_{f}^{\prime}$ 's variability in an oak forest $[16,18]$, no study has yet focused on its spatial variability in a leafless period in single oak trees.

Beyond the implications of $T_{f}$ spatial heterogeneity for soil processes, this heterogeneity also challenges constraining measuring $T_{f}$ as well as estimating $I$ [19-22]. Overall, two sampling strategies for measuring $T_{f}$ exist: stationary and roving methods. In the stationary (fixed setup) method, $T_{f}$ collectors are kept at fixed positions during the entire study period [23-28]. The roving collector method is a sampling strategy whereby the $T_{f}$ collectors are randomly relocated at regular or variable times [22,29-34]. Fewer gauges are required for estimating $T_{f}$ with high statistical confidence and a low margin of error is desirable for minimizing both cost and effort $[7,19,21,35]$, especially at the tree-based scale characterized by high spatial heterogeneity. Using fixed $T_{f}$ gauges are advantageous because there is no need to reposition them periodically; also, fixed gauges permit a detailed examination of the I process over the course of individual rainstorm events [36,37].

In many temperate regions, especially those with a Mediterranean climate, most of the rain falls when trees are leafless [38]. However, to our best knowledge, few reports studied the spatial variability of $T_{f}$ or estimated its required numbers of collectors to reliably estimate means in a deciduous stand during this leafless period. Hence, the two objectives of this field research, conducted with single Brantii oak trees (Quercus brantii var. Persica) were to (1) evaluate the $T_{f}$ sampling method (stationary method) for finding the optimal number of $T_{f}$ collectors, and (2) evaluate the spatial variability of $T_{f}$ under these sampled trees.

\section{Materials and Methods}

\subsection{Study Area}

The experimental work took place from October 2011 to March 2012 in an oak forest in western Iran $\left(46^{\circ} 24^{\prime} \mathrm{E}, 33^{\circ} 37^{\prime} \mathrm{N}, 1383 \mathrm{~m}\right.$ a.s.l). According to the leaves' phenology, one year was divided into two canopy development stages: the leafed period (from April to midOctober) and the leafless period (from mid-October to the end of March). At the research site, vegetation consists of sparse and scattered Brant's oak trees (Q. brantii var. Persica), whose understory is used for agroforestry. Long-term (1986-2017) meteorological data at the Ilam Meteorological Station ( $46^{\circ} 26^{\prime} \mathrm{E}, 33^{\circ} 38^{\prime} \mathrm{N}, 1363 \mathrm{~m}$ a.s.l, approximately $500 \mathrm{~m}$ from the study area) showed that annual averages for precipitation and air temperature were $570 \mathrm{~mm}$ and $17^{\circ} \mathrm{C}$, respectively. According to the De Martonne climate classification, the study area has a Mediterranean climate type (De Martonne Aridity Index: 21.1).

Five single, even-aged, healthy, and mature Q. brantii var Persica trees with similar morphologies of tree height, diameter at breast height (DBH), crown projected area (CPA), and height under branch were randomly selected among the trees of similar size, all located in a 2.5-ha tract (Table 1). The crowns of the five trees did not overlap with any neighboring trees. 
Table 1. Characteristics of five single Brant's oak (Quercus brantii var. Persica) trees.

\begin{tabular}{ccccc}
\hline Tree No. & DBH $\mathbf{( c m})$ & Height $(\mathbf{m})$ & Basal Area $\left(\mathbf{m}^{\mathbf{2}}\right)$ & CPA $\left(\mathbf{m}^{\mathbf{2}}\right)$ \\
\hline A & 58 & 10.0 & 0.26 & 52.8 \\
B & 66 & 5.5 & 0.34 & 58.1 \\
C & 67 & 11.0 & 0.35 & 78.5 \\
D & 75 & 10.7 & 0.44 & 45.3 \\
E & 63 & 8.4 & 0.31 & 66.4 \\
Mean & 66 & 9.1 & 0.34 & 60.2 \\
\hline
\end{tabular}

DBH: Diameter at breast height; CPA: Crown projection area.

\subsection{Field Measurements}

The $P_{g}$ was measured using six cylindrical plastic rain collectors, each $9 \mathrm{~cm}$ in diameter, placed in an adjacent clearing about $20 \mathrm{~m}$ from the sample trees (with no crown interaction). Rainfall totals were collected on a daily $(24 \mathrm{~h})$ basis. The experimental network consisted of a total of $16 T_{f}$ collectors (identical to the $P_{g}$ collectors) at each of the five trees. These $T_{f}$ collectors were randomly placed in a radial layout centered on each tree stem; along with eight azimuths, two $T_{f}$ collectors were installed at two randomly determined distances (i.e., 'near' and 'far' from the tree's stem; Figure 1). This arrangement was kept throughout the entire experiment (i.e., fixed gauges for the $T_{f}$ sampling). The quantity of water collected from the $P_{g}$ and $T_{f}$ collectors was manually measured using a graduated cylinder, to an accuracy of $1 \mathrm{~mL}$. The averaged value of the rainfall collectors installed in the open area and beneath the oak stand was used to calculate $P_{g}$ and $T_{f}$, respectively. All the $P_{g}$ and $T_{f}$ collectors were emptied and dried after each rainstorm event. Continuous daily records of wind speed and wind direction were obtained from the Ilam Meteorological Station.

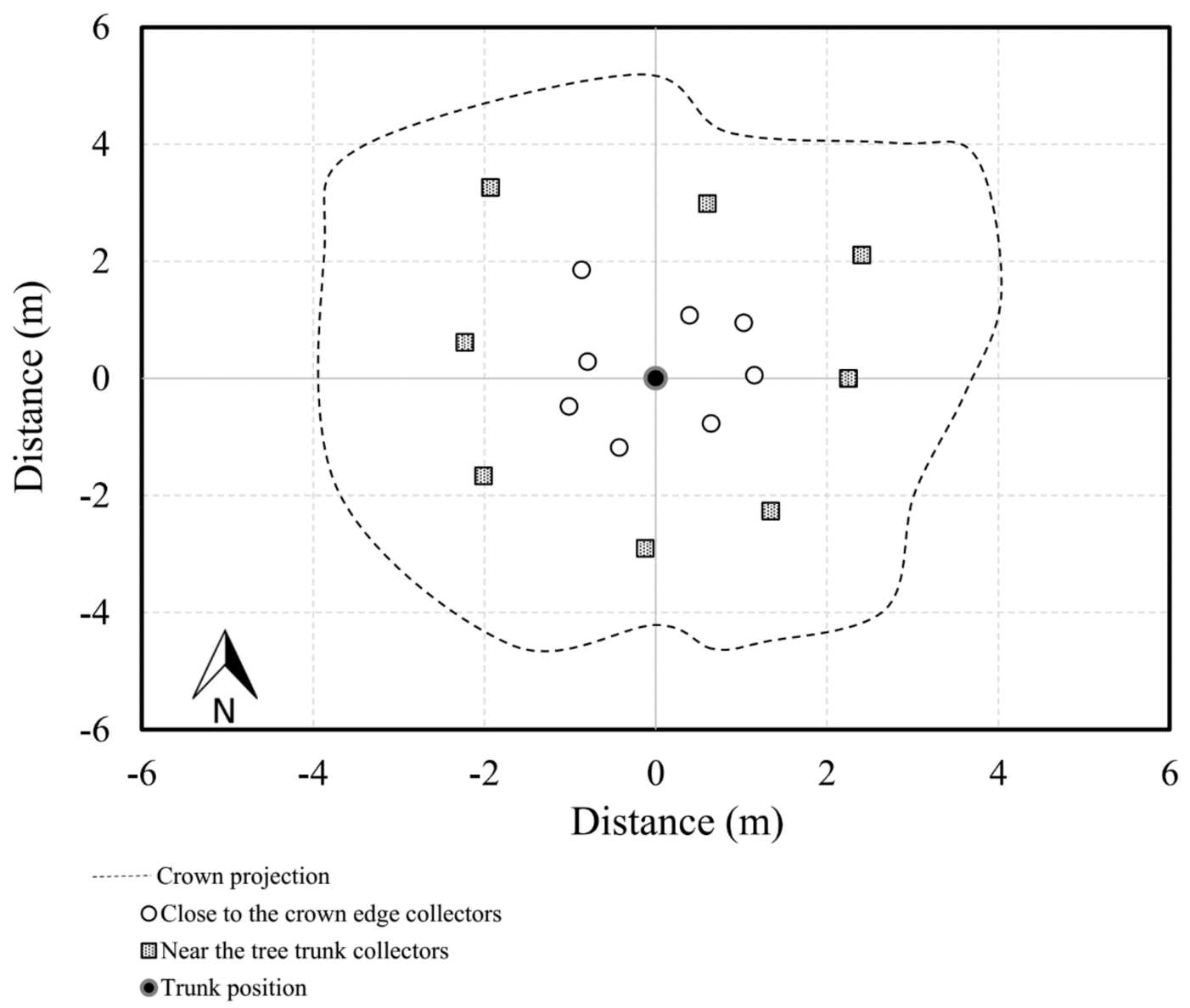

Figure 1. Spatial distribution of throughfall rain gauges used for tree A in the field study. 


\subsection{Data Analysis}

\subsubsection{Spatial Variability of Throughfall}

The spatial variability of $T_{f}$ was assessed by a variogram analysis, this being a quantitative descriptive statistic that characterizes the spatial continuity of data sets. Variograms are a useful tool for quantifying how similarity in a response variable relates to proximity to better understand the structure of spatial patterns $[15,39]$. It expresses continuity as the average of the squared difference between quantities measured at different locations.

The calculation of meaningful directional variograms when having a low number of field observations is reportedly impossible $[40,41]$. Consequently, this has precluded checks for anisotropy in the spatial variability's structure of the respective variables of interest. Nonetheless, here we sought to know whether an anisotropic spatial structure could be discernable in the $T_{f}$ process using observations from just 16 rain collectors per tree, and these were artificially increased based on the method of Sterk and Stein [40]. More details can be found in Fathizadeh et al. [7,16].

\subsubsection{Minimum Number of Throughfall Collectors}

We calculated the number of $T_{f}$ samplers of all individual trees required to determine leafless $T_{f}$ averages within acceptable error margins $(5 \%, 10 \%, 15 \%$, and $20 \%$ of the mean cumulative $\left.T_{f}\right)$ and three confidence levels $(\alpha=0.01,0.05$, and 0.1$)$, assuming the mean $T_{f}$ of all 16 samplers for each individual tree represented the true value. The minimum number of $T_{f}$ collectors $\left(N_{\min }\right)$ needed to estimate $T_{f}$ within a preset percentage of the mean $(E)$ at the $90 \%, 95 \%$, and $99 \%$ confidence interval can be estimated from a coefficient of variation of $T_{f}\left(C V_{t}\right)$, as follows [20]:

$$
N_{\min }=\frac{z_{c}^{2} \times C V_{t}^{2}}{E^{2}}
$$

where $z_{\mathcal{c}}$ is the critical value of the $90 \%, 95 \%$, and $99 \%$ confidence levels.

\subsubsection{Statistical Analysis}

The Kolmogorov-Smirnov test was used to assess the normality of the data set. The quality of each variogram was tested using a cross validation. For this, all the samples were excluded piecemeal (one each time) from the data set and iteratively re-estimated by kriging using the remaining samples. Then the observed data and predicted values were compared to evaluate the kriging results [42]. From the cross validation we estimated the mean absolute errors $(M A E)$ and the relative $M A E\left(R M A E=M A E / \overline{T_{f}}\right) . M A E$ or $R M A E$ measure how close forecasts or predictions are to the eventual outcomes. Cross validation was performed for trees with relatively suitable $T_{f}$ autocorrelation structure. Accordingly, total $T_{f}$ patterns were created for those trees having robust fitted models. Meanwhile, residual sums of squares (RSS) were estimated as a measure of how well the model fits the variogram data. More information about the methods is available in Fathizadeh et al. [16].

\section{Results}

\subsection{Throughfall Characteristics}

Over the six-month monitoring period, total gross rainfall $\left(P_{g}\right)$ was $302.4 \mathrm{~mm}$ and mean $T_{f}$, expressed on a crown-projected area basis was $259 \mathrm{~mm}(\mathrm{SD}=6.8 \mathrm{~mm})$ for 24 rainfall events. Therefore, the average interception loss equaled $14.3 \%$ of $P_{g}$. Snowfall did not occur. The mean $P_{g}$ per event was $12.6 \mathrm{~mm}(\mathrm{SD}=13.4 \mathrm{~mm}$; SE $=2.7 \mathrm{~mm})$, with high variation ranging from 0.7 to $47.3 \mathrm{~mm}(C V=1.06)$. Mean $T_{f}$ depth per event was $10.8 \mathrm{~mm}$ $(\mathrm{SD}=0.31 \mathrm{~mm})$ or $75.8 \%$ as a proportion of $P_{g}(\mathrm{SD}=4.4 \%)$.

\subsection{Throughfall Spatial Patterns}

Fitted models in multiple directions using the geostatistical analysis of $T_{f}$ amounts resulted in undetectable anisotropy for trees A, B, and E, but zonal anisotropy was dis- 
cernable in the data for trees $C$ and $D$, which the surface variogram maps show as well (Figures 2 and 3). Therefore, we assumed an isotropic correlation structure for the former trees. A spherical model fitted for trees A and B yielded a stable sill emerging at about 2.3 and $3.5 \mathrm{~m}$, respectively. The range over which spatial dependence is apparent was estimated to be $\sim 1 \mathrm{~m}$ for an exponential model fitted for tree E. The other two trees (i.e., $\mathrm{C}$ and D) were fitted with linear models and these had an unclear stable sill (Figure 3, Table 2).
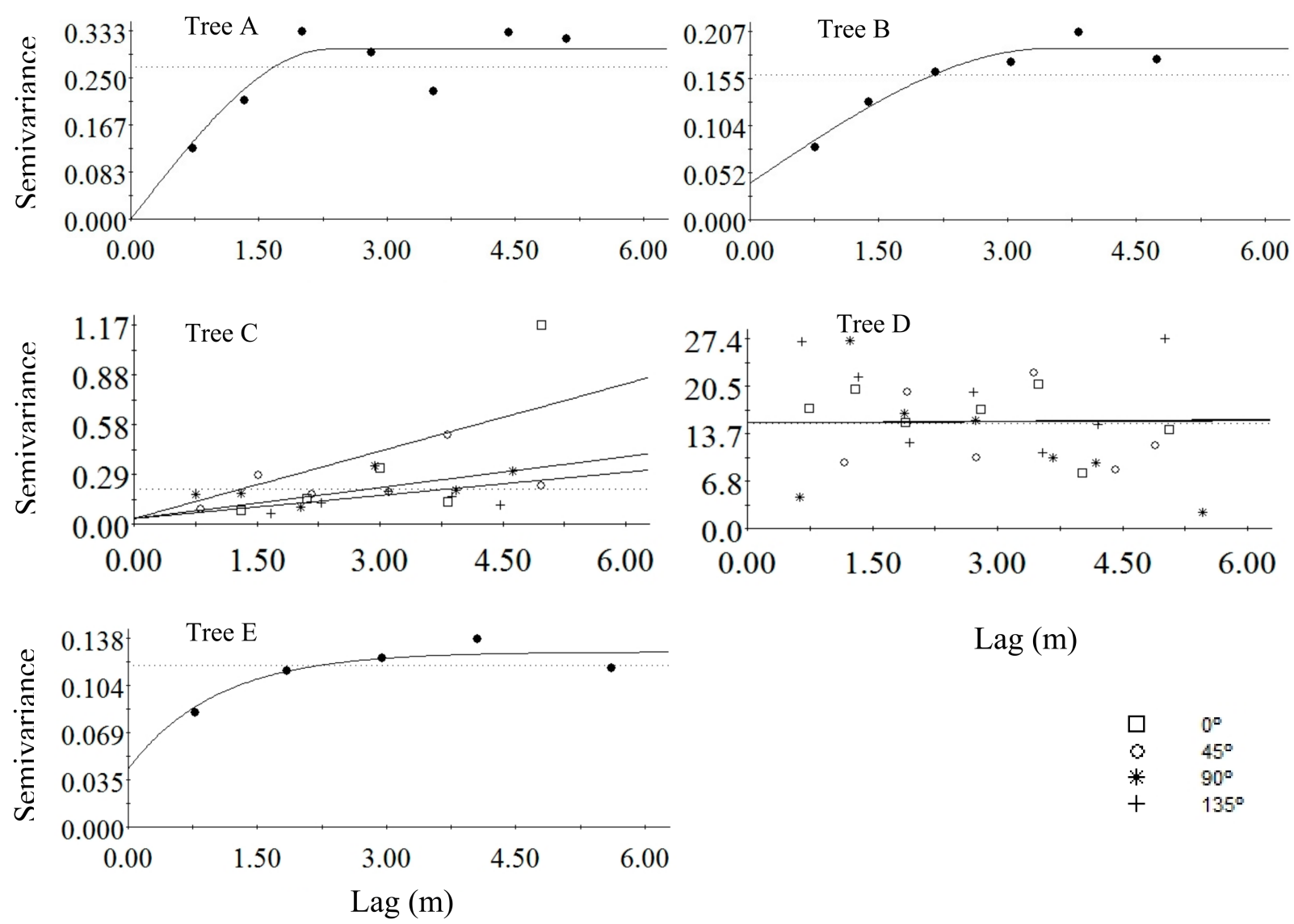

$\operatorname{Lag}(\mathrm{m})$

Figure 2. Experimental isotropic (for trees $\mathbf{A}, \mathbf{B}$, and $\mathbf{E}$ ) and anisotropic (for trees $\mathbf{C}$ and $\mathbf{D}$ ) variograms for throughfall (mm) and fitted models in multiple directions for trees $\mathbf{C}$ and D. Details for fitting models are available in Fathizadeh et al. [16].

Table 2. Key characteristics of the variogram models for individual oak trees. RSS: residual sums of squares that provide a measure of how well the model fitted the variogram data; $\mathrm{A}_{0}$ : range parameter; $A_{1}$ : the range parameter for the major axis of variation; $A_{2}$ : the range parameter for the minor axis; $C_{0}$ : nugget effect, and the ratio between structural variance $(C)$ and sill $\left(C_{0}+C\right)$ parameters. ${ }^{*}$ isotropic model, ${ }^{* *}$ anisotropic model.

\begin{tabular}{cccccccc}
\hline Tree & Theoretical Model & $\mathbf{r}^{\mathbf{2}}$ & $\mathbf{R S S}$ & $\mathbf{A}_{\mathbf{0}}$ & $\mathbf{A}_{\mathbf{1}}$ & $\mathbf{A}_{\mathbf{2}}$ & $\mathbf{C} /\left(\mathbf{C}_{\mathbf{0}}+\mathbf{C}\right)$ \\
\hline A & $*$ Spherical & 0.77 & 0.009 & 2.32 & & & $\sim 1$ \\
B & $*$ Spherical & 0.93 & 0.00069 & 3.48 & & & 0.79 \\
C & $* *$ Linear & 0.33 & 0.672 & & 26.35 & 9.06 & 0.97 \\
D & $* *$ Linear & 0.12 & 1170 & & 557.7 & 348.1 & 0.64 \\
E & $*$ Exponential & 0.84 & 0.003 & 1.03 & & & 0.67 \\
\hline
\end{tabular}


Semivariance Tree A
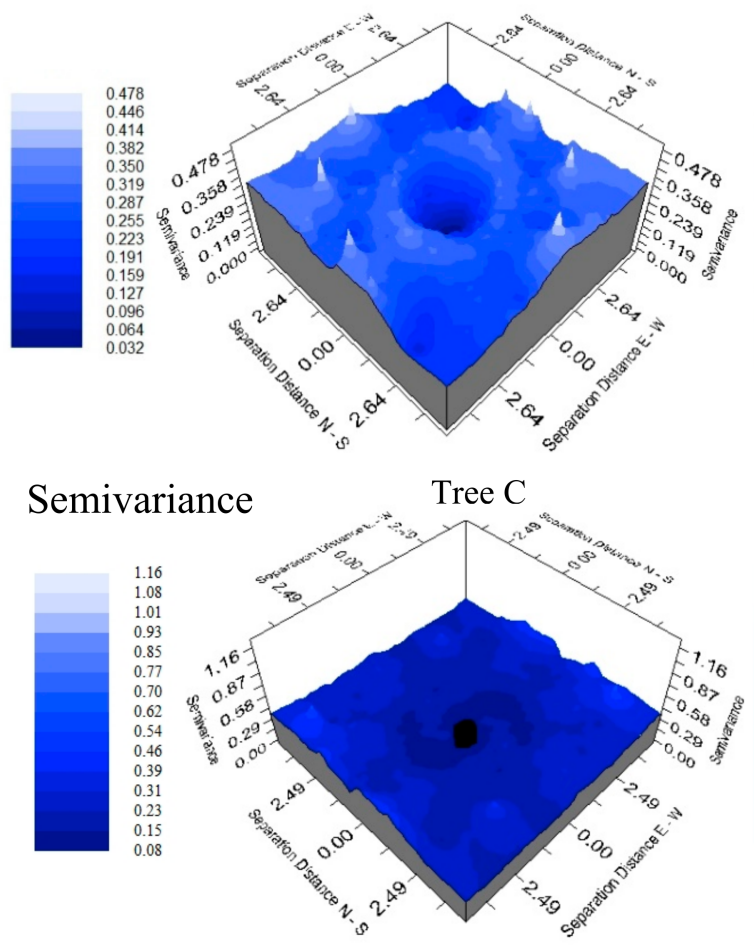

Semivarian

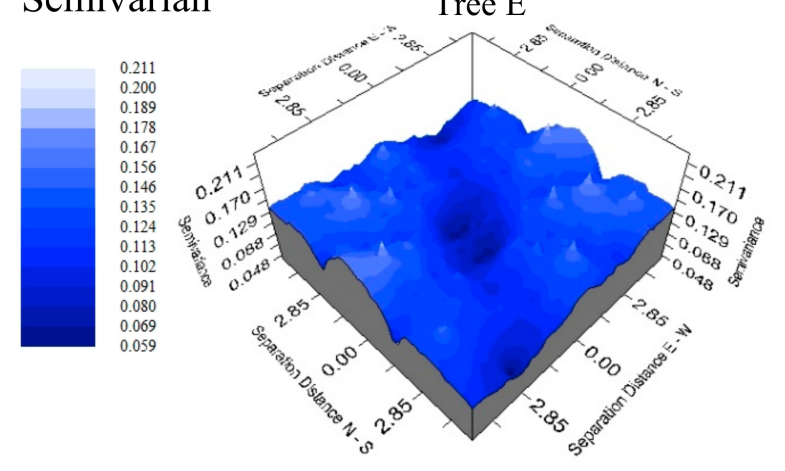

Tree B
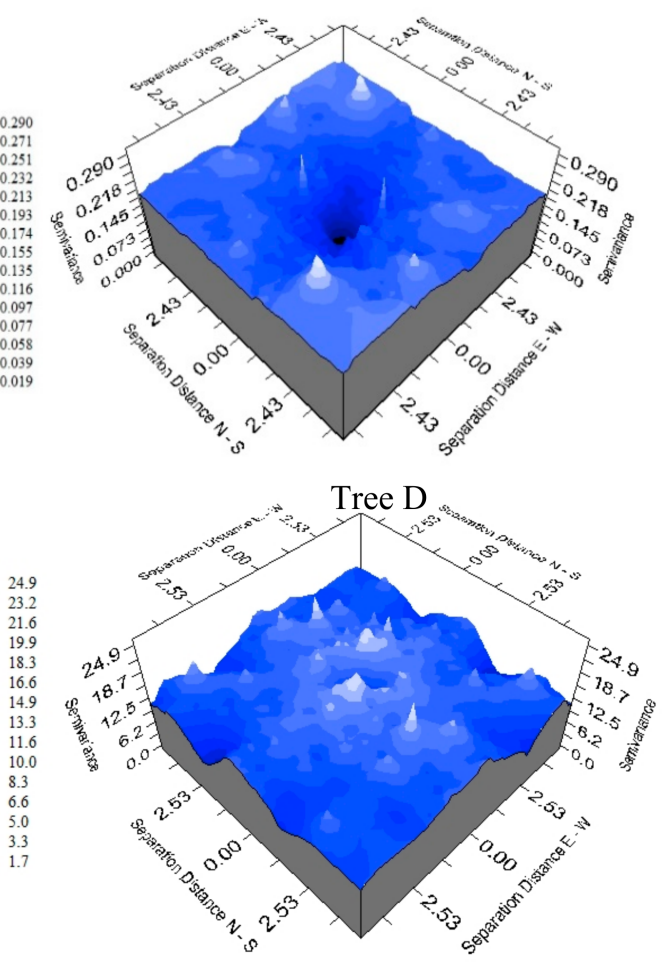

Figure 3. Surface variogram maps of throughfall $(\mathrm{mm})$ in the west-east (W-E) and north-south (N-S) directions, calculated for five individual Brant's oak trees.

Cross validation was performed for five single trees and all 24 rainfall events during the leafless period, producing MAE and RMAE (Table 3). According to the results of previous analysis, described in Fathizadeh et al. [16], only those rainfall events with an RMAE $<30 \%$ were used to generate the spatial patterns of $T_{f}$ via kriging (Figure 4 ). Evidently, there were patchy spatial distributions of $T_{f}$ under trees $\mathrm{A}, \mathrm{B}$, and $\mathrm{E}$ (i.e., trees with an autocorrelation structure), its values being generally lower near the tree trunk. When quantitatively estimated for all trees, the average cumulative $T_{f}$ was $235.4 \mathrm{~mm}$ ( $\mathrm{SD}=24.3 \mathrm{~mm}$ ) or $77.8 \%$ of $P_{g}$ for collectors near the tree trunk, $17.6 \%$ less than average cumulative $T_{f}\left(288.7 \mathrm{~mm}\right.$, or $95.5 \%$ of $\left.P_{g} ; \mathrm{SD}=19.9 \mathrm{~mm}\right)$ for collectors positioned close to the crown edge (i.e., far from the tree trunk; Table 4). Except for tree B ( $t$-test, $F=1.271$, $t(14)=-2.436, p<0.05)$, the average cumulative $T_{f}$ of collectors near the crown edge and tree bole were not significantly different ( $t$-test; $\alpha=0.05$ ). Considering that all five trees experienced the same meteorological conditions, it seems that tree $\mathrm{E}$ has a less physically heterogynous crown than do the others, in that most of its canopy has redistributed $T_{f}$ values for $50-80 \%$ of $P_{g}$ (Figure 4 ). The $T_{f}$ areas exceeding $100 \%$ were observed under all single trees, but presentable only for trees A, B, and E via kriged maps, mostly at the crown 
margins (Figure 4). The spatial variability of $T_{f}$ can be expressed using the coefficient of variation $(C V)$, i.e., the standard deviation as a proportion of the mean. The mean $C V$ of cumulative $T_{f}$ amount was $25 \%$, ranging from $17.9 \%$ for tree $\mathrm{E}$ to $28.8 \%$ for tree $\mathrm{B}$ (Table 3 ).

Tree A

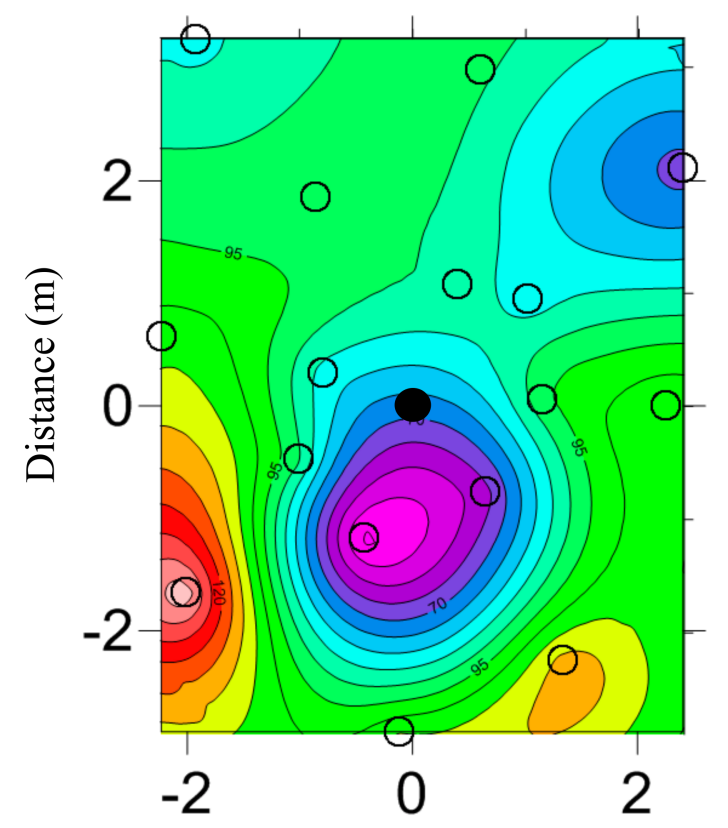

Tree E

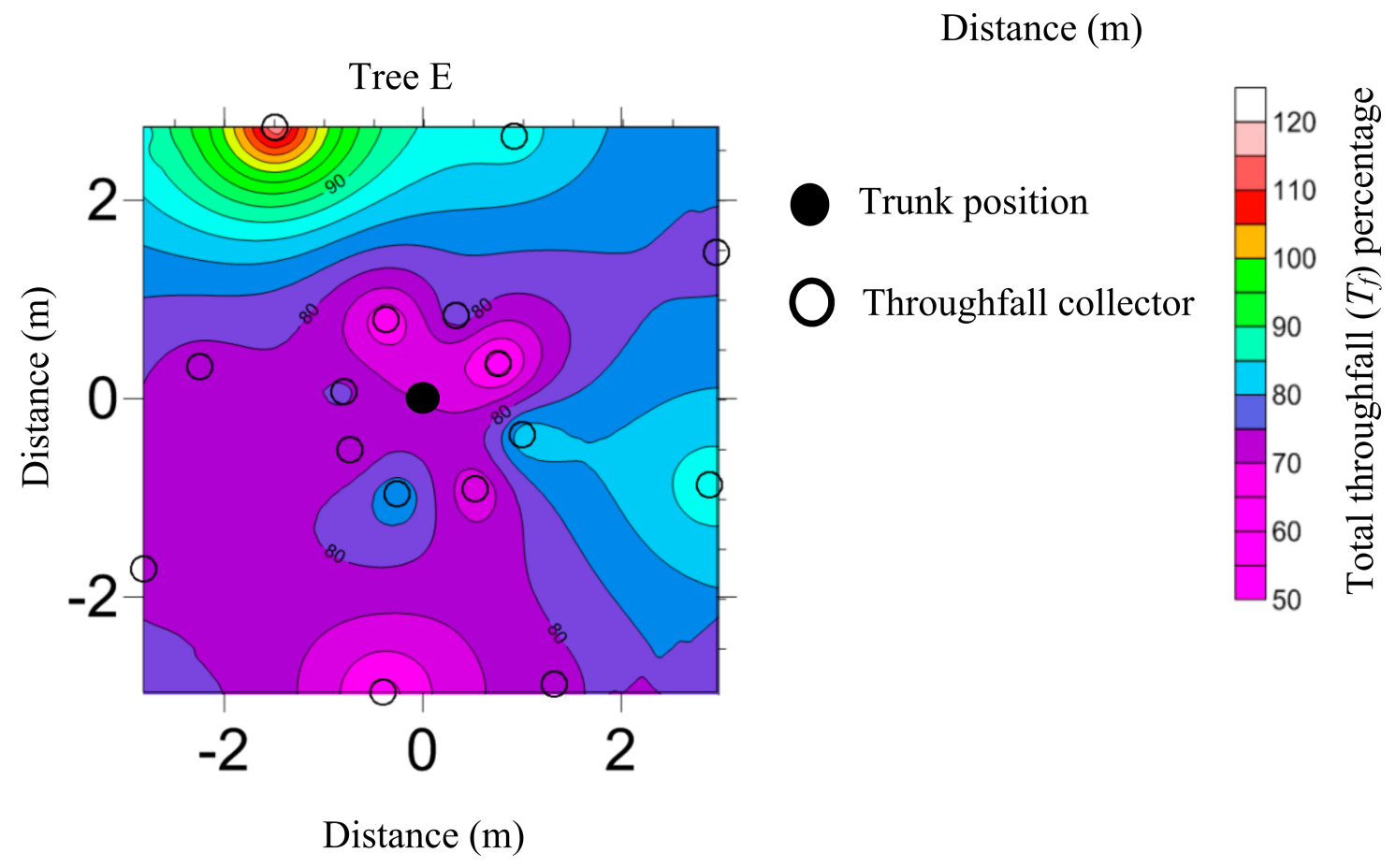

Tree B

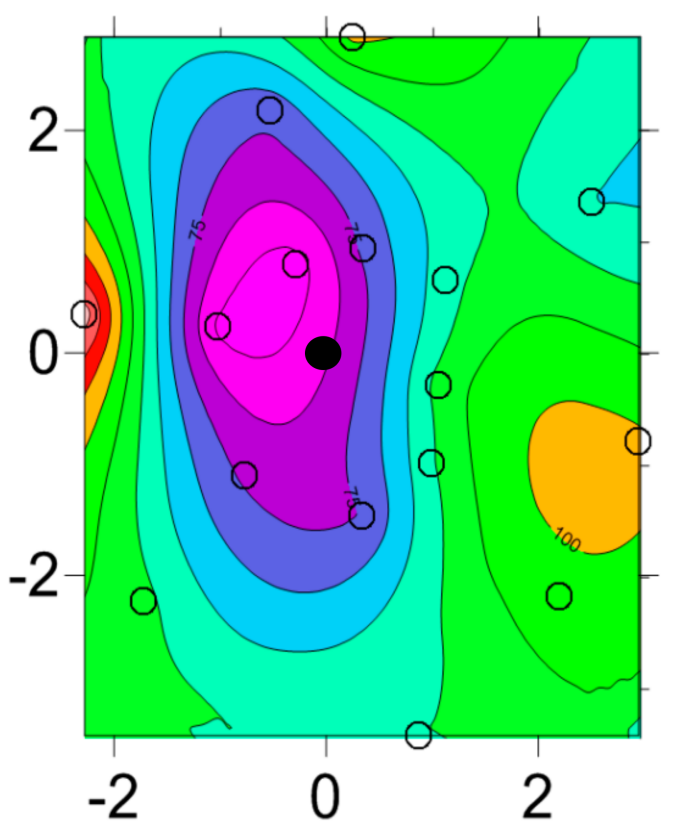

Distance (m)

Figure 4. Kriged maps of total $T_{f}$ for trees A, B, and E, calculated as the ratio between the sum of individual $T_{f}$ events with a relative mean absolute errors (RMAE) $<30 \%$ and total rainfall during those events, multiplied by 100 . 
Table 3. Storm characteristics and results of cross-validations for five individual oak trees.

\begin{tabular}{|c|c|c|c|c|c|c|c|c|c|c|c|c|c|c|c|c|c|}
\hline \multirow{2}{*}{$\begin{array}{l}\text { Rainstorm } \\
\text { Event }\end{array}$} & \multirow{2}{*}{$\begin{array}{c}P g \\
(\mathrm{~mm})\end{array}$} & \multicolumn{4}{|c|}{ Tree A } & \multicolumn{4}{|c|}{ Tree B } & \multicolumn{2}{|c|}{ Tree C } & \multicolumn{2}{|c|}{ Tree D } & \multicolumn{4}{|c|}{ Tree E } \\
\hline & & $\begin{array}{c}T_{f} \\
(\mathrm{~mm})\end{array}$ & $\begin{array}{l}\text { MAE } \\
(\mathrm{mm})\end{array}$ & $\begin{array}{c}\text { RMAE } \\
(\%)\end{array}$ & Skewness & $\begin{array}{c}T_{f} \\
(\mathrm{~mm})\end{array}$ & $\begin{array}{l}\text { MAE } \\
(\mathrm{mm})\end{array}$ & $\begin{array}{c}\text { RMAE } \\
(\%)\end{array}$ & Skewness & $\begin{array}{c}T_{f} \\
(\mathrm{~mm})\end{array}$ & Skewness & $\begin{array}{c}T_{f} \\
(\mathrm{~mm})\end{array}$ & Skewness & $\begin{array}{c}T_{f} \\
(\mathrm{~mm})\end{array}$ & $\begin{array}{l}\text { MAE } \\
(\mathrm{mm})\end{array}$ & $\begin{array}{c}\text { RMAE } \\
(\%)\end{array}$ & Skewness \\
\hline 1 & 16.4 & 13.2 & 3.1 & 23.6 & 0.52 & 13.1 & 4.8 & 36.9 & $1.1 \log$ & 8.2 & -0.06 & 12 & 0.05 & 10.3 & 2.8 & 27.1 & 0.79 \\
\hline 2 & 39.1 & 38.4 & 7 & 18.2 & 0.81 & 38.3 & 5.9 & 15.5 & $0.81 \log$ & 32.6 & 0.25 & 38.2 & -1.22 & 37.8 & 8.7 & 23 & $1.06 \log$ \\
\hline 3 & 5.2 & 4.3 & 1.1 & 24.6 & 0.17 & 4.2 & 0.9 & 21.5 & 0.83 & 3.4 & 0.33 & 4 & -0.54 & 3.7 & 0.9 & 24.8 & 0.56 \\
\hline 4 & 24.9 & 20 & 3.7 & 18.6 & -0.35 & 18.8 & 4.5 & 23.9 & 0.12 & 22.1 & $1.34 \log$ & 18.4 & -0.88 & 19.1 & 5.7 & 30 & 0.36 \\
\hline 5 & 2.3 & 1.5 & 0.47 & 31.3 & 0.64 & 1.4 & 0.17 & 12.3 & 0.7 & 1.1 & $1.64 \log$ & 1.4 & 0.24 & 1.2 & 0.3 & 22.8 & 0.22 \\
\hline 6 & 2 & 1.3 & 0.43 & 31.8 & 0.01 & 1.2 & 0.37 & 32.8 & 0.55 & 1.1 & -0.09 & 1.2 & -0.49 & 1.2 & 0.3 & 23.7 & 0.4 \\
\hline 7 & 3.3 & 2.6 & 0.61 & 23.7 & -0.4 & 2.5 & 0.47 & 18.8 & 0.13 & 1.9 & -0.16 & 2.4 & -1.13 & 2.7 & 0.4 & 16.2 & 0.43 \\
\hline 8 & 47.3 & 41.1 & 10.1 & 24.6 & $0.03 \log$ & 39 & 9.4 & 24 & -0.16 & 39.3 & 1.77log & 38.4 & 0 & 38.8 & 7.8 & 20.1 & 0.79 \\
\hline 9 & 24.9 & 24.3 & 5.2 & 21.2 & 0.78 & 23.4 & 5.3 & 22.5 & $1.21 \log$ & 24 & $1.20 \mathrm{log}$ & 23.6 & -0.23 & 23.6 & 7.2 & 30.6 & $0.75 \log$ \\
\hline 10 & 28.5 & 27.7 & 4.8 & 17.3 & 0.03 & 26.7 & 5.8 & 21.8 & 0.19 & 26.6 & $1.38 \log$ & 27.4 & 0.53 & 27.6 & 8.3 & 30.1 & 0.53 \\
\hline 11 & 25.1 & 23.7 & 3.5 & 14.9 & -0.29 & 24.2 & 7.5 & 31.1 & $1.59 \log$ & 21.6 & $0.45 \log$ & 23.7 & -1.1 & 22.5 & 7.4 & 32.7 & -0.17 \\
\hline 12 & 1.9 & 1.4 & 0.3 & 21.4 & -0.46 & 1.4 & 0.25 & 18.1 & $0.11^{\circ}$ & 1 & 0.39 & 1.3 & -0.04 & 1.2 & 0.26 & 21.7 & 0.05 \\
\hline 13 & 6.4 & 6.1 & 1.4 & 22 & 0.24 & 5.7 & 2.6 & 46.8 & $1.09 \log$ & 4.9 & -0.71 & 5.4 & -0.71 & 5.1 & 1.6 & 30.7 & -0.03 \\
\hline 14 & 0.81 & 0.55 & 0.19 & 34.3 & -0.16 & 0.34 & 0.13 & 37.6 & 0.43 & 0.2 & -0.88 & 0.43 & -0.06 & 0.3 & 0.12 & 39.6 & 0.7 \\
\hline 15 & 2.1 & 1.5 & 0.6 & 40.6 & $0.43 \log$ & 1.4 & 0.86 & 61.5 & 0.83 & 1.1 & 0.05 & 1.3 & $0.29 \log$ & 1.4 & 0.85 & 60.6 & 0.83 \\
\hline 16 & 13.3 & 12.5 & 1.5 & 11.7 & -1.32 & 12.1 & 3.1 & 25.3 & $1.42 \log$ & 11.3 & 1.14log & 12 & 0.14 & 11.7 & 3.9 & 33 & 0.46 \\
\hline 17 & 1.6 & 0.97 & 0.18 & 18.7 & -0.67 & 1.1 & 0.36 & 34.7 & 0.86 & 0.8 & $0.42 \log$ & 1.1 & -0.46 & 1 & 0.24 & 25.2 & 0.47 \\
\hline 18 & 2.4 & 2.1 & 0.52 & 24.4 & -1.31 & 1.8 & 0.49 & 27.2 & 0 & 1.4 & -0.2 & 1.9 & -0.97 & 1.5 & 0.58 & 37.9 & -0.23 \\
\hline 19 & 16 & 14.1 & 2.5 & 17.9 & -0.46 & 13.5 & 3.5 & 26 & 0.23 & 12.8 & 0.86 & 14.1 & -1.19 & 13.6 & 2.7 & 20 & -0.44 \\
\hline 20 & 3.9 & 3.7 & 0.78 & 21.2 & -1.27 & 3.3 & 0.63 & 19.5 & -0.01 & 3.1 & -0.29 & 3.6 & -0.86 & 3.3 & 1 & 31 & -0.07 \\
\hline 21 & 0.66 & 0.43 & 0.17 & 38.9 & 0.33 & 0.44 & 0.18 & 41 & 0.64 & 0.3 & 0.63 & 0.47 & $0.08 \log$ & 0.4 & 0.1 & 17.4 & 0 \\
\hline 22 & 3.7 & 3.2 & 0.78 & 24.3 & -1.27 & 2.8 & 0.61 & 21.8 & 0.25 & 2.7 & $0.32 \log$ & 3.1 & -0.61 & 2.9 & 1 & 34.8 & -0.01 \\
\hline 23 & 5.9 & 5.1 & 1.3 & 25.8 & 0.36 & 4.6 & 2.1 & 44.6 & $1.03 \log$ & 4.4 & $0.75 \log$ & 4.9 & -0.52 & 4.5 & 1.5 & 34.5 & 0.14 \\
\hline 24 & 24.5 & 22.7 & 5.1 & 22.7 & 0.78 & 22.3 & 5 & 22 & $0.78^{\circ}$ & 21.9 & 0.93 & 22.8 & -0.23 & 22.5 & 7.2 & 32.1 & $0.71 \log$ \\
\hline Cumulative & 302.2 & 272.5 & & & & 263.6 & & & & 247.8 & & 263.1 & & 257.9 & & & \\
\hline Mean & 12.59 & 11.35 & 2.31 & 23.9 & -0.12 & 10.98 & 2.71 & 28.63 & 0.61 & 10.33 & 0.48 & 10.96 & -0.41 & 10.75 & 2.95 & 29.15 & 0.35 \\
\hline $\begin{array}{l}\text { Coefficient of } \\
\text { variation (\%) }\end{array}$ & & & & 22.8 & & & & 28.8 & & & 27.9 & & 27.4 & & & 17.9 & \\
\hline
\end{tabular}


Table 4. Average cumulative throughfall ( $\mathrm{mm}$ and \%) under individual Brant's oak tree canopies, spatially estimated near the tree trunk and far from it (i.e., close to crown edge).

\begin{tabular}{|c|c|c|c|c|c|c|c|c|c|c|}
\hline \multirow{3}{*}{ Distance from Trunk } & \multicolumn{10}{|c|}{ Trees } \\
\hline & \multicolumn{2}{|c|}{ A } & \multicolumn{2}{|c|}{ B } & \multicolumn{2}{|c|}{$\mathrm{C}$} & \multicolumn{2}{|c|}{ D } & \multicolumn{2}{|c|}{ E } \\
\hline & $\mathbf{m m}$ & $\%$ & $\mathrm{~mm}$ & $\%$ & $\mathbf{m m}$ & $\%$ & $\mathrm{~mm}$ & $\%$ & $\mathbf{m m}$ & $\%$ \\
\hline Close to the crown edge & 301.9 & 99.8 & 303.6 & 100.4 & 305.7 & 101.1 & 277.7 & 91.8 & 254.4 & 84.1 \\
\hline Near the tree trunk & 242.5 & 80.2 & 235.5 & 73.9 & 189.7 & 62.7 & 248.4 & 82.2 & 260.9 & 86.3 \\
\hline
\end{tabular}

At the rainfall-event level, the spatial $C V$ of $T_{f}$ had a tendency of decreasing with an increasing rainfall amount, with a median value of $33.7 \%$ (Figure 5). During the study period, the $C V$ of $T_{f}$ declined from a median value of $72.1 \%$ for a $2.1-\mathrm{mm}$ rainfall event to stabilize at a median value of $32.2 \%$ for those events with at least $10 \mathrm{~mm}$ rainfall for the single studied trees.

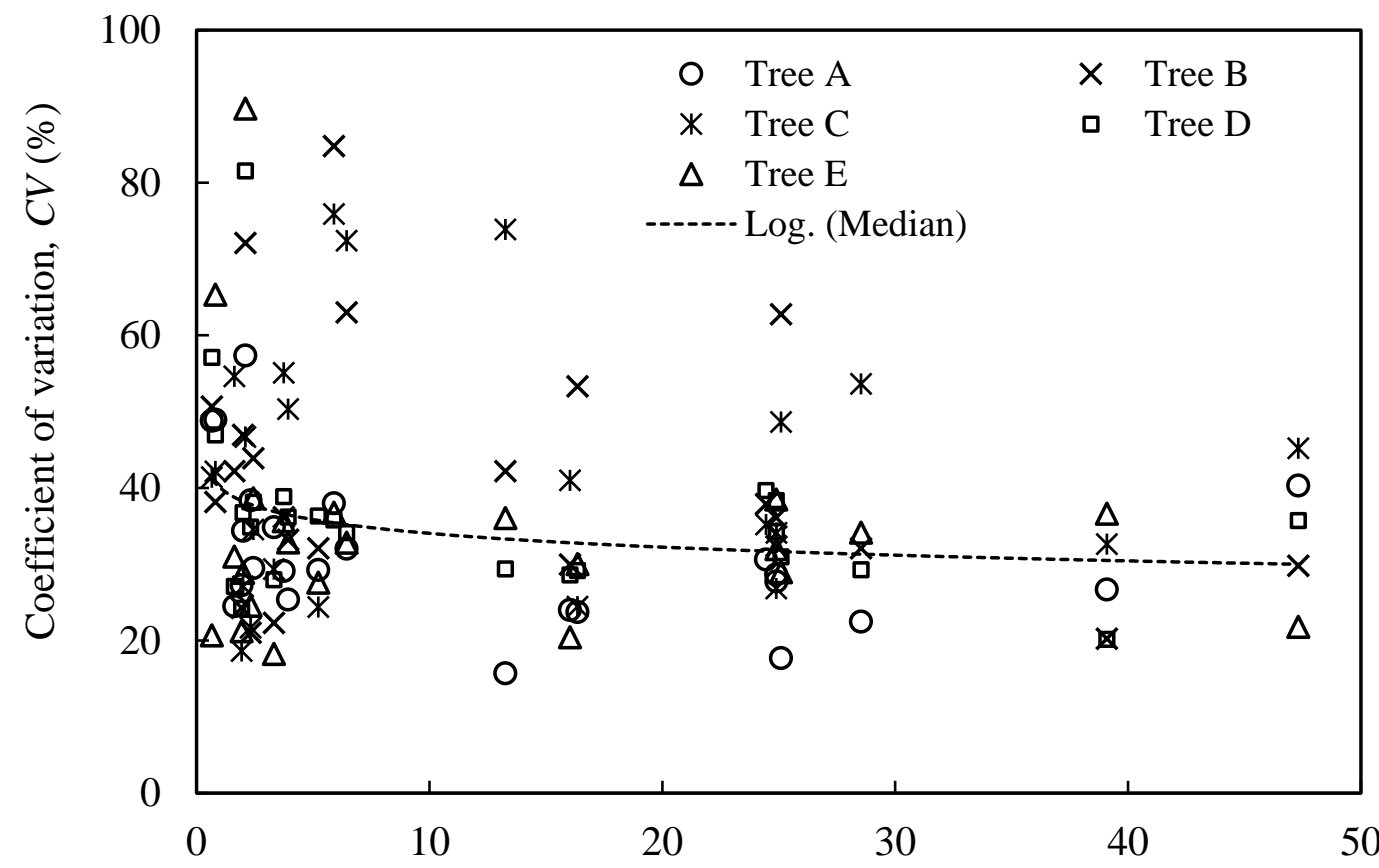

Gross rainfall, $P_{g}(\mathrm{~mm})$

Figure 5. Decline of the spatial coefficient of variation (\%) of throughfall with increasing rainfall magnitude $(\mathrm{mm})$ for rainfall events during the leafless period $(n=24)$. A logarithmic trend line was fitted to the median values of the data.

\subsection{Minimum Number of Throughfall Collectors}

We present the results of Equation (1) used to calculate the minimum $T_{f}$ collectors needed to keep the relative error of the mean below $20 \%, 10 \%$, or $5 \%$, for the 24 original data sets. The average number of $T_{f}$ collectors required to ensure the relative error is below $20 \%$ varies between $5(\alpha=0.10)$ and $14(\alpha=0.01)$. The corresponding numbers for a relative error $\leq 15 \%$ were $9(\alpha=0.10)$ and $25(\alpha=0.01)$; likewise, the number of collectors needed to estimate the mean $T_{f} \pm 10 \%$ were $20(\alpha=0.10)$ and $55(\alpha=0.01)$, and for a mean $T_{f} \pm 5 \%$ they were $79(\alpha=0.10)$ and $220(\alpha=0.10)$. According to Equation (1), as an example, for tree $A$ and an acceptable error of $10 \%$ of the mean $T_{f}$, the required number of collectors was estimated to be $24(\alpha=0.05)$ (Table 5, Figure 6$)$. These results suggested that 13 collectors are sufficient to estimate mean cumulative $T_{f}$ with an error of $15 \%$ and a confidence interval of $95 \%$ (Table 5). The improvement in the mean and $C V$ of $T_{f}$ volume (as explained via 
the error of mean $T_{f}$ ) arising from additional collectors is shown in Figure 6. The most dramatic improvement occurred during the addition of the first 10 collectors (Figure 6). Generally, once about 20 collectors are used, the relation between the number of collectors and the mean $T_{f}$ error plateau, achieving a near-zero slope (Figure 6). Hence, above this number, little improvement would be achieved by adding more collectors to the sampling network beneath trees. Moreover, and perhaps not surprisingly, we found that more $T_{f}$ collectors are needed for trees with a higher $C V$ (tree B, C, and D) (Figure 6, Table 5).
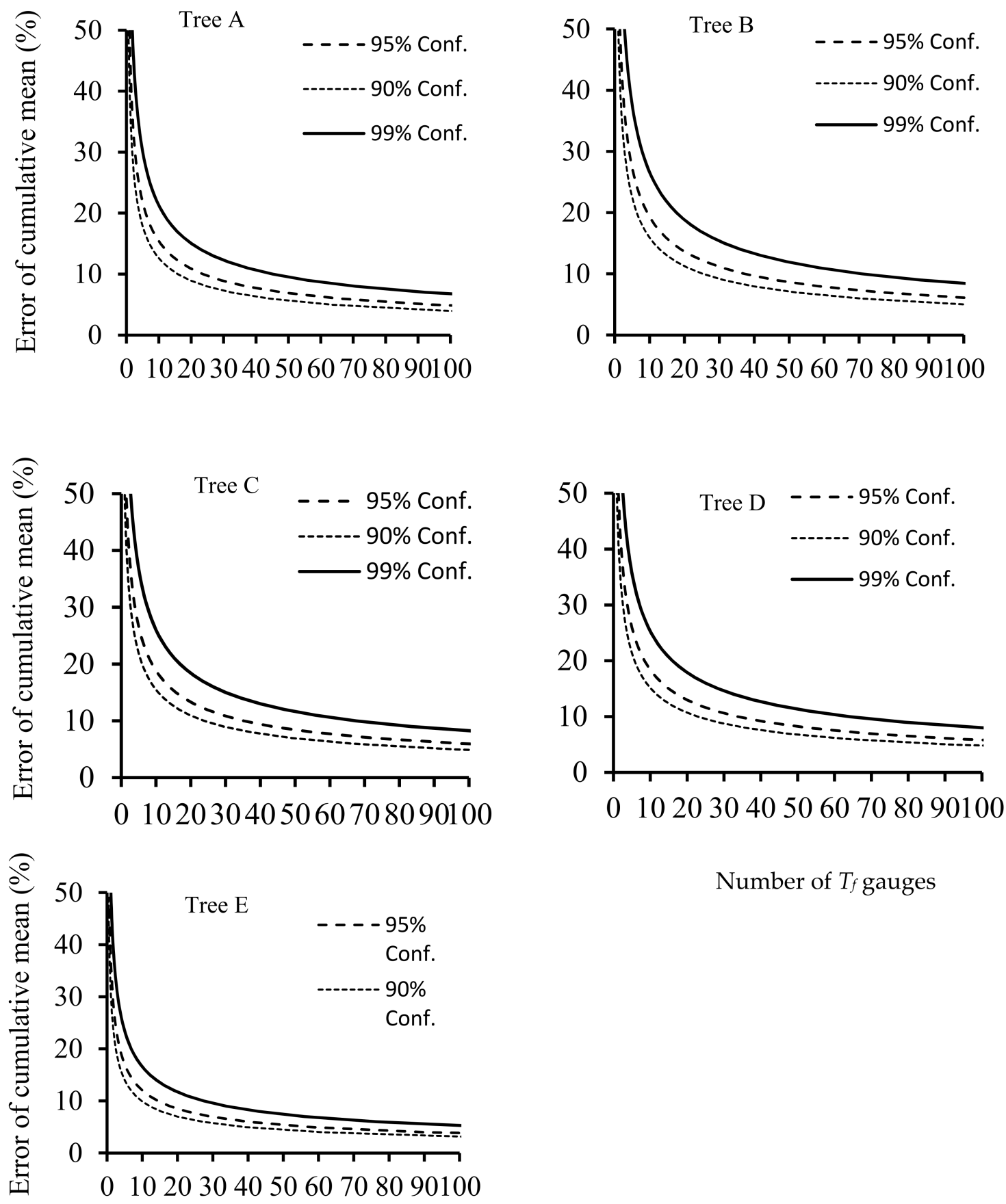

Number of $T_{f}$ gauges

Number of $T_{f}$ gauges

Figure 6. Error of cumulative throughfall volume as a function of the number of throughfall collectors, for three different confidence intervals, at the five studied individual Brant's oak trees. 
Table 5. The estimated number of required throughfall $\left(T_{f}\right)$ gauges for individual Brant's oak trees.

\begin{tabular}{|c|c|c|c|c|c|c|c|c|c|c|c|c|c|c|c|}
\hline \multirow{4}{*}{$\begin{array}{c}\text { Error of Cumulative } T_{f} \\
\text { Mean (\%) }\end{array}$} & \multicolumn{15}{|c|}{ Trees } \\
\hline & \multicolumn{3}{|c|}{$\mathbf{A}$} & \multicolumn{3}{|c|}{ B } & \multicolumn{3}{|c|}{$\mathrm{C}$} & \multicolumn{3}{|c|}{ D } & \multicolumn{3}{|c|}{$\mathbf{E}$} \\
\hline & \multicolumn{15}{|c|}{ Confidence Interval (\%) } \\
\hline & 90 & 95 & 99 & 90 & 95 & 99 & 90 & 95 & 99 & 90 & 95 & 99 & 90 & 95 & 99 \\
\hline 5 & 64 & 95 & 181 & 102 & 150 & 284 & 96 & 142 & 271 & 92 & 135 & 256 & 40 & 58 & 110 \\
\hline 10 & 16 & 24 & 46 & 26 & 38 & 71 & 24 & 36 & 68 & 23 & 34 & 64 & 10 & 15 & 28 \\
\hline 15 & 8 & 11 & 21 & 12 & 17 & 32 & 11 & 16 & 31 & 11 & 15 & 29 & 5 & 7 & 13 \\
\hline 20 & 4 & 6 & 12 & 7 & 10 & 18 & 6 & 9 & 17 & 6 & 9 & 16 & 3 & 4 & 7 \\
\hline
\end{tabular}

\section{Discussion}

\subsection{Throughfall Spatial Pattern}

The partitioning of rainfall measured during the six months under single oak trees in the leafless period $\left(T_{f}=85.7 \%\right.$ of $\left.P_{g}\right)$ differed considerably from our previous research on the same trees in their leafed period $\left(T_{f}=68.9 \%\right.$ of $\left.P_{g}\right)$ [16]. The spatial patterns of $T_{f}$, as quantified by its spatial continuity measured with variograms clearly varied among the five trees. This could be attributed to the differences in canopy structure factors (e.g., Wood Area Index, branching angle, canopy width) among the trees. The cumulative $T_{f}$ under single oak trees was spatially autocorrelated up to a range of about 1-3.5 $\mathrm{m}$ in the leafless period, overlapping to some extent with the 3-5 $\mathrm{m}$ that has been observed for the leafed period [16]. Similar variogram studies of small-scale spatial $T_{f}$ autocorrelation are scarce; for example, 1-3 $\mathrm{m}$ for the isolated olive trees in Spain [41] and 3-4 m for an individual deciduous beech tree in Belgium [43], and likewise at the stand scale; for example, 6-7 m for a 120-year-old beech forest in Luxembourg [44]; 2-6 $\mathrm{m}$ for a 42-year-old mixed-hardwood forest [45]; 2.6, 5.3, and $3.9 \mathrm{~m}$ in a teak plantation, young secondary forest, and an old secondary forest, respectively [46]; and 4-6 $\mathrm{m}$ in a rubber plantation [47]. However, $T_{f}$ in an old-growth tropical wet forest in Costa Rica indicated an autocorrelation range of $43 \mathrm{~m}$ because of the high structural variability of the forests caused by large areas dominated by either individual tree canopies or by treefall gaps [48]. A spatial correlation distance of $12 \mathrm{~m}$ and $8 \mathrm{~m}$ was detected for spring and summer, respectively, in a Douglas-fir stand in the Netherlands [49], whereas no spatial autocorrelation was observed for $T_{f}$ in a holm-oak forest [50]. As we mentioned in our previous study [16], differences in the spatial correlation of $T_{f}$ can be ascribed to the differences among canopy species and in canopy structure, density, spatial homogeneity, and meteorological phenomena [15]. Staelens et al. [43] related the small spatial range of $T_{f}$ to no spatial dependence existing in these studies because the minimum sampling distance exceeded the possibly present spatial range of $T_{f}$ variability. In other words, using a higher minimum intermediate distance of $T_{f}$ collectors that fails to sample at short lags can result in a lack of information on spatial autocorrelation at scales below $0.5 \mathrm{~m}$. Close to the tree trunks, more branches and leaves intercepted the $T_{f}$, which resulted in its lower value at this position. Conversely, those sub-canopy areas where $T_{f}$ surpassed incident rainfall were observed in spatial patterns at trees A, B, and E (Figure 4), mostly lying close to the crown edge and main branches, where intercepted water is apt to get channeled downward. This result could also be partly attributed to extreme fog events, wherein fog entrapment by the canopy leads to an enhanced $T_{f}$ volume [51,52]. The fog during the leafless period is very common due to the Mediterranean climate, therefore, the hydrological importance of fog should be considered in future hydrological studies.

For $T_{f}$ volumes, their spatial $C V$ was $25 \%$ for oak single trees in the leafless period, similar to that previously observed for their leafed period $(C V=26.7 \%)$ [16]. Compared with our study, beneath the crown of one dominant beech (Fagus sylvatica L.) tree in Belgium, Staelens et al. [43] found less spatial $C V(8 \%)$ for $T_{f}$ during its leafless period. Spatial variations in $T_{f}$ may be explained by canopy cover structure and wind combined $[8,15,18,29,43]$. 
Indeed, the high spatial variability of $T_{f}$ in the leafless period in our study could be explained by possible effects from non-vertical rainfall and a non-homogeneous distribution of raindrops driven by turbulent air flow, both above and within the canopy, because of local windy conditions during winter [53]. Due to the presence of wind, raindrops fall inhomogeneous with a tree canopy. Moreover, $T_{f}$ variability has a tendency of decreasing with an increasing $P_{g}$ (Figure 5) through a constant median value of around $32 \%$ for $P_{g} \geq 10 \mathrm{~mm}$. Our findings agree with previous studies reporting that the $C V$ diminishes with a greater magnitude of rainfall events [21,53-55]. A plausible explanation is that the canopy becomes saturated when rainfall is more than $10 \mathrm{~mm}$, such that any extra rainfall is mostly shunted to $T_{f}$ with no interception by the tree canopy $[29,33,56,57]$.

\subsection{Minimum Number of Throughfall Collectors}

It is hard to estimate $T_{f}$ accurately using a minimum number of $T_{f}$ collectors because of difficulties in achieving a high spatial representation of $T_{f}$ measurements [58,59]. To obtain a proper estimate of the average $T_{f}$, many collectors would be required [15,60], which entails considerable time and effort. Therefore, it is necessary to try to estimate what would be a suitable number of $T_{f}$ collectors for reliably estimating $T_{f}$ at the scale of a single tree. As indicated in Figure 6 and Table 5, if the goal is for 95\% of resampled means to lie within a $10 \%$ error of the overall mean $T_{f}, 29$ collectors should be used. Some scholars suggest that a lower number of collectors could be used to estimate the volume of $T_{f}$, albeit accepting a higher margin of error [61,62]. Our resampling results indicate a progressive narrowing of the variability of cumulative mean $T_{f}$ as the number of collectors used increases. This result is similar to the findings of Puckett [61], who arrived at 11 for a minimum number of collectors to produce mean $T_{f}$ values limited to a $10 \%$ error and a $95 \%$ confidence interval. In our work with 29 collectors, adding one more collector would reduce considerably the variability of the $T_{f}$ means. Therefore, an effort to implement more collectors in this interval represents a considerable improvement in the determination of the mean cumulative $T_{f}$. There are many reasons why different minimum numbers of $T_{f}$ collectors have been reported across research sites. Apart from the influence of tree species' traits, a difference in the $T_{f}$ collectors' sizes is likely also a major factor influencing the inferred number of collectors [63].

The optimal design of $T_{f}$ collectors for estimating the mean $T_{f}$ depends on the temporal scale of sampling, as well as forest complexity [46]. The measurement of $T_{f}$ is a critical phase in the evaluation of $I$ because a significant error in the $T_{f}$ term results in corresponding over- or under-estimates of I. Based on our results for Brant's oak during its leafless period, we now also know how an individual crown contributes to lateral water translocation within the tree crown at fine spatial scales. This study can contribute to making an informed determination of the number of how many $T_{f}$ collectors would be needed for the robust estimates of mean $T_{f}$ and their associated error. One of the most important implications of our results concerns the determination of canopy ecohydrological parameters. In most studies that model $I$, parameters such as canopy saturation point, canopy storage capacity, free throughfall, and evaporation rate during rainfall are derived by plotting $T_{f}$ against $P_{g}$ (reviewed by Friesen et al. [64]). Hence, the accuracy of these derived canopy ecohydrological parameters depends on the accuracy of the $P_{g}$ and $T_{f}$ measurements from which they were derived.

\section{Conclusions}

Although within the range reported by similar studies, the spatial variability of throughfall water $\left(T_{f}\right)$ investigate here using the $C V$ s under single Brant's oak trees did not match up well, implying significant seasonal differences between the leafed and the leafless periods. The present study confirms that tree canopies modify the spatial distribution of $T_{f}$ reaching the forest floor during their leafless period. The $T_{f}$ quantity for single oak trees during their leafless period differed significantly from that during their leafed period, probably because of non-vertical rainfall profiles and the non-homogeneous distribution 
of raindrops above and within the canopy during winter. However, the spatial $C V$ for $T_{f}$ volumes during the leafless period was 25\%, similar to the leafed period. Mostly, those $T_{f}$ areas exceeding incident rainfall were found close to the crown edge, where the downfacing branches at the crown edge probably channeled the intercepted water to the forest floor. Conversely, near the tree trunks is where more intercepted water was transported to stem and converted to stemflow rather than $T_{f}$, leading to lower $T_{f}$ values there.

We conclude that using $29 T_{f}$ collectors is adequate for estimating the $T_{f}$ value with an accepted error of $10 \%$ at the $95 \%$ confidence level. The very important tree characteristic for considering $T_{f}$ spatial distribution is the characteristic of the canopy above the observed point, so we recommend measuring this parameter in future research. To gain further insight, long-term studies employing different $T_{f}$ collectors and sizes are now needed to draw comprehensive conclusions.

Author Contributions: O.F. conceived the idea and performed the experiment. O.F., S.M.M.S., I.P., S.G. and P.A. analyzed data and wrote the manuscript. L.S. reviewed and approved the final manuscript. All authors have read and agreed to the published version of the manuscript.

Funding: This work was supported by the National Natural Science Foundation of China (41807158).

Data Availability Statement: The data presented in this study are available on request from the first author.

Acknowledgments: This paper is extracted from the final report of the research project entitled "Spatial variability of throughfall under single Brant's oak trees during the leafless period" which has been implemented from the research credits of University of Tabriz. We would like to thank Richard F. Keim at Louisiana State University and Scott T. Allen at University of Nevada for their assistance in editing a draft of this manuscript.

Conflicts of Interest: The authors declare no conflict of interest.

\section{References}

1. Llorens, P.; Domingo, F. Rainfall partitioning by vegetation under Mediterranean conditions: A review of studies in Europe. J. Hydrol. 2007, 335, 37-54. [CrossRef]

2. Sadeghi, S.M.M.; Gordon, A.; Van Stan, J.T. A global synthesis of throughfall and stemflow hydrometeorology. In Precipitation Partitioning by Vegetation: A Global Synthesis; Gutmann, E., Friesen, J., Eds.; Springer: Cham, Switzerland, 2020; pp. 49-70.

3. Fathizadeh, O.; Hosseini, S.M.; Keim, R.F.; Boloorani, A.D. A seasonal evaluation of the reformulated Gash interception model for semi-arid deciduous oak forest stands. For. Ecol. Manag. 2018, 409, 601-613. [CrossRef]

4. Sadeghi, S.M.M.; Attarod, P.; Pypker, T.G.; Dunkerley, D. Is canopy interception increased in semiarid tree plantations? Evidence from a field investigation in Tehran, Iran. Turk. J. Agric. For. 2014, 38, 792-806. [CrossRef]

5. Su, L.; Zhao, C.; Xu, W.; Xie, Z. Hydrochemical Fluxes in bulk precipitation, throughfall, and stemflow in a mixed evergreen and deciduous broadleaved forest. Forests 2019, 10, 507. [CrossRef]

6. Zabret, K.; Šraj, M. Spatial variability of throughfall under single birch and pine tree canopies. Acta Hydrotech. 2018, 31, 1-20. [CrossRef]

7. Fathizadeh, O.; Sadeghi, S.M.M.; Holder, C.D.; Su, L. Leaf phenology drives spatio-temporal patterns of throughfall under a single Quercus castaneifolia C.A. Mey. Forests 2020, 11, 688. [CrossRef]

8. Zimmermann, A.; Wilcke, W.; Elsenbeer, H. Spatial and temporal patterns of throughfall quantity and quality in a tropical montane forest in Ecuador. J. Hydrol. 2007, 343, 80-96. [CrossRef]

9. Coenders-Gerrits, A.M.J.; Hopp, L.; Savenije, H.H.G.; Pfister, L. The effect of spatial throughfall patterns on soil moisture patterns at the hillslope scale. Hydrol. Earth Syst. Sci. 2013, 17, 1749-1763. [CrossRef]

10. Van Stan, J.T.; Hildebrandt, A.; Friesen, J.; Metzger, J.C.; Yankine, S.A. Spatial Variability and Temporal Stability of Local Net Precipitation Patterns. In Precipitation Partitioning by Vegetation: A Global Synthesis; Gutmann, E., Friesen, J., Eds.; Springer: Cham, Switzerland, 2020; pp. 89-104.

11. Herwitz, S.R. Raindrop impact and water flow on the vegetative surfaces of trees and the effects on stemflow and throughfall generation. Earth Surf. Proc. Land. 1987, 12, 425-432. [CrossRef]

12. Sato, A.M.; Avelar, A.D.; Netto, A.L.C. Spatial variability and temporal stability of throughfall in a eucalyptus plantation in the hilly lowlands of southeastern Brazil. Hydrol. Process. 2011, 25, 1910-1923. [CrossRef]

13. Johnson, R.C. The interception, throughfall and stemflow in a forest in highland Scotland and the comparison with other upland forests in the U.K. J. Hydrol. 1990, 118, 281-287. [CrossRef]

14. Whelan, M.J.; Sanger, L.J.; Baker, M.; Anderson, J.M. Spatial patterns of throughfall and mineral ion deposition in a lowland Norway spruce (Picea abies) plantation at the plot scale. Atmos. Environ. 1998, 32, 3493-3501. [CrossRef] 
15. Keim, R.F.; Skaugset, A.E.; Weiler, M. Temporal persistence of spatial patterns in throughfall. J. Hydrol. 2005, 314, $263-274$. [CrossRef]

16. Fathizadeh, O.; Attarod, P.; Keim, R.F.; Zahedi Amiri, G.; Davishsefat, A.A. Spatial heterogeneity and temporal stability of throughfall under individual Quercus brantii trees. Hydrol. Process. 2014, 28, 1124-1136. [CrossRef]

17. Nanko, K.; Onda, Y.; Ito, A.; Moriwaki, H. Spatial variability of throughfall under a single tree: Experimental study of rainfall amount, raindrops, and kinetic energy. Agric. For. Meteorol. 2011, 151, 1173-1182. [CrossRef]

18. Carlyle-Moses, D.E.; Laureano, J.S.F.; Price, A.G. Throughfall and throughfall spatial variability in Madrean oak forest communities of northeastern Mexico. J. Hydrol. 2004, 297, 124-135. [CrossRef]

19. Helvey, J.D.; Patric, J.H. Design criteria for interception studies. In Proceedings of the Symposium on Design of Hydrological Networks, Quebec, QC, Canada, 15-22 June 1965; pp. 131-137.

20. Kimmins, J.P. Some statistical aspects of sampling throughfall precipitation in nutrient cycling studies in British Columbian coastal forests. Ecology 1973, 54, 1008-1019. [CrossRef]

21. Holwerda, F.; Scatena, F.N.; Bruijnzeel, L.A. Throughfall in a Puerto Rican lower montane rain forest: A comparison of sampling strategies. J. Hydrol. 2006, 327, 592-602. [CrossRef]

22. Ritter, A.; Regalado, C.M. Roving revisited, towards an optimum throughfall sampling design. Hydrol. Process. 2014, $28,123-133$. [CrossRef]

23. Fathizadeh, O.; Attarod, P.; Pypker, T.G.; Darvishsefat, A.A.; Amiri, G.Z. Seasonal variability of rainfall interception and canopy storage capacity measured under individual oak (Quercus brantii) trees in Western Iran. J. Agric. Sci. Tech. 2013, 15, 175-188.

24. Abbasian, P.; Attarod, P.; Sadeghi, S.M.M.; Van Stan, J.T.; Hojjati, S.M. Throughfall nutrients in a degraded indigenous Fagus orientalis forest and a Picea abies plantation in the North of Iran. For. Syst. 2015, 24, 1-15. [CrossRef]

25. Attarod, P.; Sadeghi, S.M.M.; Pypker, T.G.; Bagheri, H.; Bagheri, M.; Bayramzadeh, V. Needle-leaved trees impacts on rainfall interception and canopy storage capacity in an arid environment. New For. 2015, 46, 339-355. [CrossRef]

26. Attarod, P.; Rostami, F.; Dolatshahi, A.; Sadeghi, S.M.M.; Amiri, G.Z.; Bayramzadeh, V. Do changes in meteorological parameters and evapotranspiration affect declining oak forests of Iran? J. For. Sci. 2016, 62, 553-561. [CrossRef]

27. Attarod, P.; Sadeghi, S.M.M.; Pypker, T.G.; Bayramzadeh, V. Oak trees decline; a sign of climate variability impacts in the west of Iran. Casp. J. Environ. Sci. 2017, 15, 373-384.

28. Gordon, D.A.R.; Coenders-Gerrits, M.; Sellers, B.A.; Sadeghi, S.M.M.; Van Stan, J.T. Rainfall interception and redistribution by a common North American understory and pasture forb, Eupatorium capillifolium (Lam. dogfennel). Hydrol. Earth Syst. Sci. 2020, 24, 4587-4599. [CrossRef]

29. Fathizadeh, O.; Hosseini, S.M.; Zimmermann, A.; Keim, R.F.; Boloorani, A.D. Estimating linkages between forest structural variables and rainfall interception parameters in semi-arid deciduous oak forest stands. Sci. Total Environ. 2017, 601, 1824-1837. [CrossRef]

30. Hakimi, L.; Sadeghi, S.M.M.; Van Stan, J.T.; Pypker, T.G.; Khosropour, E. Management of pomegranate (Punica granatum) orchards alters the supply and pathway of rain water reaching soils in an arid agricultural landscape. Agric. Ecosyst. Environ. 2018, 259, 77-85. [CrossRef]

31. Sadeghi, S.M.M.; Van Stan, J.T.; Pypker, T.G.; Friesen, J. Canopy hydrometeorological dynamics across a chronosequence of a globally invasive species, Ailanthus altissima (Mill., tree of heaven). Agric. For. Meteorol. 2017, 240, 10-17. [CrossRef]

32. Sadeghi, S.M.M.; Attarod, P.; Van Stan, J.T.; Pypker, T.G. The importance of considering rainfall partitioning in afforestation initiatives in semiarid climates: A comparison of common planted tree species in Tehran, Iran. Sci. Total Environ. 2016, 568, 845-855. [CrossRef] [PubMed]

33. Sadeghi, S.M.M.; Van Stan, J.T.; Pypker, T.G.; Tamjidi, J.; Friesen, J.; Farahnaklangroudi, M. Importance of transitional leaf states in canopy rainfall partitioning dynamics. Eur. J. For. Res. 2018, 137, 121-130. [CrossRef]

34. Nazari, M.; Sadeghi, S.M.M.; Van Stan, J.T.; Chaichi, M.R. Rainfall interception and redistribution by maize farmland in central Iran. J. Hydrol. Reg. Stud. 2020, 27, 100656. [CrossRef]

35. Lloyd, C.R.; de Marques, F. Spatial variability of throughfall and stemflow measurements in Amazonian Rainforest. Agric. For Meteorol. 1988, 42, 63-73. [CrossRef]

36. Link, T.E.; Unsworth, M.; Marks, D. The dynamics of rainfall interception by a seasonal temperate rainforest. Agric. For. Meteorol. 2004, 124, 171-191. [CrossRef]

37. Ziegler, A.D.; Giambelluca, T.W.; Nullet, M.A.; Sutherland, R.A.; Tantasarin, C.; Vogler, J.B.; Negishi, J.N. Throughfall in an evergreen-dominated forest stand in northern Thailand: Comparison of mobile and stationary methods. Agric. For. Meteorol. 2009, 149, 373-384. [CrossRef]

38. Dolatshahi, A. Sensitivity of Evapotranspiration to Climate Change in the Northern Zagros Region, West of Iran. Master's Thesis, University of Tehran, Tehran, Iran, 2015.

39. Zimmermann, A.; Zimmermann, B.; Elsenbeer, H. Rainfall redistribution in a tropical forest: Spatial and temporal patterns. Water Resour. Res. 2009, 45, W11413. [CrossRef]

40. Sterk, G.; Stein, A. Mapping wind-blown mass transport by modeling variability in space and time. Soil Sci. Soc. Am. J. 1997, 61, 232-239. [CrossRef]

41. Gomez, J.A.; Vanderlinden, K.; Giraldez, J.V.; Fereres, E. Rainfall concentration under olive trees. Agric. Water Manag. 2002, 55, 53-70. [CrossRef] 
42. Webster, R.; Oliver, M.A. Sample adequately to estimate variograms of soil properties. J. Soil Sci. 1992, 43, 177-192. [CrossRef]

43. Staelens, J.; Schrijver, A.D.; Verheyen, K.; Verhoest, N.E.C. Spatial variability and temporal stability of throughfall water under a dominant beech (Fagus sylvatica L.) tree in relationship to canopy cover. J. Hydrol. 2006, 330, 651-662. [CrossRef]

44. Gerrits, A.M.J.; Pfister, L.; Savenije, H.H.G. Spatial and temporal variability of canopy and forest floor interception in a beech forest. Hydrol. Process. 2010, 24, 3011-3025. [CrossRef]

45. Hsueh, Y.H.; Allen, S.T.; Keim, R.F. Fine-scale spatial variability of throughfall amount and isotopic composition under a hardwood forest canopy. Hydrol. Process. 2016, 30, 1796-1803. [CrossRef]

46. Zimmermann, A.; Zimmermann, B. Requirements for throughfall monitoring: The roles of temporal scale and canopy complexity. Agric. For. Meteorol. 2014, 189, 125-139. [CrossRef]

47. Liu, J.; Liu, W.; Li, W.; Jiang, X.; Wu, J. Effects of rainfall on the spatial distribution of the throughfall kinetic energy on a small scale in a rubber plantation. Hydrol. Sci. J. 2018, 63, 1078-1090. [CrossRef]

48. Loescher, H.W.; Powers, J.S.; Oberbauer, S.F. Spatial variation of throughfall volume in an old-growth tropical wet forest, Costa Rica. J. Trop. Ecol. 2002, 18, 397-407. [CrossRef]

49. Cisneros Vaca, C.; Ghimire, C.P.; Van der Tol, C. Spatial patterns and temporal stability of throughfall in a mature Douglas-fir Forest. Water 2018, 10, 317. [CrossRef]

50. Bellot, J.; Escarre, A. Stemflow and throughfall determination in a resprouted Mediterranean holm-oak forest. Ann. For. Sci. 1998, 55, 847-865. [CrossRef]

51. Wilcke, W.; Yasin, S.; Valarezo, C.; Zech, W. Change in water quality during the passage through a tropical montane rain forest in Ecuador. Biogeochemistry 2001, 55, 45-72. [CrossRef]

52. Fleischbein, K.; Wilcke, W.; Goller, R.; Boy, J.; Valarezo, C.; Zech, W.; Knoblich, K. Rainfall interception in a lower montane forest in Ecuador: Effects of canopy properties. Hydrol. Process. 2005, 19, 1355-1371. [CrossRef]

53. Herwitz, S.R.; Slye, R.E. 3-Dimensional modeling of canopy tree interception of wind-driven rainfall. J. Hydrol. 1995, 168, 205-226. [CrossRef]

54. Sun, X.; Onda, Y.; Chiara, S.; Kato, H.; Gomi, T. The effect of strip thinning on spatial and temporal variability of throughfall in a Japanese cypress plantation. Hydrol. Process. 2015, 29, 5058-5070. [CrossRef]

55. Su, L.; Xie, Z.; Xu, W.; Zhao, C. Variability of throughfall quantity in a mixed evergreen-deciduous broadleaved forest in central China. J. Hydrol. Hydromech. 2019, 67, 225-231. [CrossRef]

56. Sadeghi, S.M.M.; Attarod, P.; Pypker, T.G. Differences in rainfall interception during the growing and non-growing seasons in a Fraxinus rotundifolia Mill. plantation located in a semiarid climate. J. Agric. Sci. Tech. 2015, 17, 145-156.

57. Sadeghi, S.M.M.; Attarod, P.; Van Stan, J.T.; Pypker, T.G.; Dunkerley, D. Efficiency of the reformulated Gash's interception model in semiarid afforestations. Agric. For. Meteorol. 2015, 201, 76-85. [CrossRef]

58. Deguchi, A.; Hattori, S.; Park, H.T. The influence of seasonal changes in canopy structure on interception loss: Application of the revised Gash model. J. Hydrol. 2006, 318, 80-102. [CrossRef]

59. Fang, S.; Zhao, C.; Jian, S. Spatial variability of throughfall in a Pinus tabulaeformis plantation forest in Loess Plateau, China. Scand. J. For. Res. 2016, 31, 467-476. [CrossRef]

60. Wullaert, H.; Pohlert, T.; Boy, J.; Valarezo, C.; Wilcke, W. Spatial throughfall heterogeneity in a montane rain forest in Ecuador: Extent, temporal stability and drivers. J. Hydrol. 2009, 377, 71-79. [CrossRef]

61. Puckett, L.J. Estimates of ion sources in deciduous and coniferous throughfall. Atmos. Environ. 1990, 24, 545-555. [CrossRef]

62. Lawrence, G.B.; Fernandez, I.J. A reassessment of areal variability of throughfall deposition measurements. Ecol. Appl. 1993, 3, 473-480. [CrossRef]

63. He, Z.B.; Yang, J.J.; Du, J.; Zhao, W.Z.; Liu, H.; Chang, X.X. Spatial variability of canopy interception in a spruce forest of the semiarid mountain regions of China. Agric. For. Meteorol. 2014, 188, 58-63. [CrossRef]

64. Friesen, J.; Lundquist, J.; Van Stan, J.T. Evolution of forest precipitation water storage measurement methods. Hydrol. Process. 2015, 29, 2504-2520. [CrossRef] 